\title{
INFANTICIDE: THE WORTH OF AN INFANT UNDER LAW*
}

\author{
by
}

\author{
CATHERINE DAMME**
}

\section{INTRODUCTION}

[After Joanna le Vagh had been charged with the death of her daughter,] [t]he jury de odio et atia in 1284 found that she had killed her in a frenzy while raving mad .... Edward I pardoned her at once on the strength of that verdict. ${ }^{1}$

Because the judge, prosecutor and defense attorney agreed that 19 year old Melissa Norris was insane in April [1976] when she beat her 3-month-old son to death while trying to exorcise "Satan", she was found not guilty by reason of insanity and will not go to prison. [Because the judge later ruled] that Miss Norris now is sane, she also cannot be sent to a mental hospital. So she walked out of the ... courtroom free."

Although over seven hundred years separates the two infanticide prosecutions described above, the contemporary societies' attitudes toward this crime dictated identical outcomes-acquittal or pardon by reason of temporary insanity.

How a society values the health, safety and welfare of its members is reflected in how and to what extent the state protects its citizens through law.

An unsettled aspect of the state's obligation to its people is whether the infant can command the same degree of protection as other citizens. This paper will examine this question and will survey how the infant's life is valued and protected and at what time the infant acquires personhood sufficient to command full protection of the state.

The focus of the paper will be on infanticide and its special status; the context for analysis will be the Anglo-American legal system. I will look at English medieval attitudes towards the practice of infanticide in ecclesiastical courts, in secular (royal) tribunals, and at common law, and will trace the evolution of this body of law which culminated in a series of English statutes specifically proscribing child-killing.

Penalties for infanticide will be of particular interest, and comparison will be made to penalties for homicide as well as the use of the special defence of criminal insanity. From the historical perspective of medieval attitudes, I will search for evidences of survival of those views in laws in the United States relating to (1) abortion, (2) proxy consent to medical treatment, and (3) euthanasia of defective newborns. Perhaps an

*Research for this paper was supported, in part, by DHEW grant GM 19513. The author wishes to express deep appreciation to Stuart W. Hinds, M.D., M.R.C.P., for first suggesting this topic and lending his enthusiastic support.

**Catherine Damme, J.D., M.P.H., Senior Research Associate, Medical Genetics Center, University of Texas Health Science Center, Graduate School of Biomedical Sciences, Houston, Texas 77030, U.S.A.

\footnotetext{
${ }^{1}$ Naomi Hurnard, The king's pardon for homicide before 1307 A.D., Oxford, Clarendon Press, 1969, pp. 163-164.

2 Washington Post, 16 September 1976, p. D1, col. 1.
} 


\section{Catherine Damme}

exploration of the feeling toward child-killing in history and law will better the understanding of society's attitudes embodied in law concerning the worth of an infant's life.

What is proposed here is that infanticide has always been unique in history in its incidence, commission, pleading, defence, and penalty. Infanticide, without regard to societal mores, is simple homicide-the taking of another's life. But within the AngloAmerican jurisprudential traditions, the "another's life" has not included the newborn infant. Indeed, the fact that infanticide has a demonstrated separateness in history attests to the infant's special status. Moreover, the inescapable conclusion to be drawn from the laws proscribing infanticide is that this special status is in fact lesser status than that of an adult or even a more fully developed child.

\section{INFANTICIDE IN MEDIEVAL ENGLAND}

Medieval English society had a decidedly ambivalent attitude toward infanticide. While contemporary commentators on secular law such as Bracton and Fleta defined homicide and murder in ways which clearly included an infant in rerum natura, ${ }^{3}$ the king's justice seldom extended to such occurrences, and jurisdiction fell upon ecclesiastical courts.

That infanticide did occur frequently in medieval England is beyond dispute. A markedly higher male sex ratio among heirs (four to three) in Inquisition post mortem from 1250 to 1348 and from 1430 to 1545 led Josiah Russell to speculate that female infants had been victims of infanticide." And, after examining serf lists of the late 1300s, Russell commented:

The difference in numbers of boys and girls is extraordinary out of 128 children 78 males to 46 females .... Either the liquidation of females among the serfs was much more common than among the favored classes or there is some peculiarity in the collection of the evidence. The first possibility has some basis in the necessity for restricting the number of children in view of the limited opportunities open to people of the class. The possibility of a peculiar bias in the collection of the evidence is somewhat more difficult to explain."

The theory that the victims were most often female is also in harmony with the needs of what was a predominantly agrarian and military society. ${ }^{\circ}$

Moreover, an examination of the church court records of Canterbury in the fifteenth century adequately supports the contention that such crimes did indeed take place, but the incidence is impossible to gauge. As R. H. Helmholz comments: "One wants inevitably to know, how much infanticide was there? And to this question the [Canterbury parish records] give no reliable answer. The largest number of prosecutions for the crime I have found for any one year is four." ?

The paucity of quantitative data should not invalidate the theory that infanticide

- Cyril C. Means jr., 'The phoenix of abortional freedom', N.Y. Law Forum, 1971, 17: 335-410, pp. 339-340 and 349; H. G. Richardson and G. O. Sayles (eds.), Fleta, London, Bernard Quaritch, Selden Society, 1955, p. 60.

- Barbara A. Kellum, 'Infanticide in England in the later Middle Ages', History of Childhood Quarterly, 1974, 1: 367-388, p. 368.

Ibid., p. 368.

- Mary M. McLaughlin, 'Survivors and surrogates', in L. DeMause (ed)., The history of childhood, New York, Psychohistory Press, 1974, p. 120.

' R. H. Helmholz, 'Infanticide in the Province of Canterbury during the fifteenth century', History of Childhood Quarterly, 1974, $1: 379-390$, p. 384. 


\section{Infanticide: the worth of an infant under law}

was fairly widespread. Records, both ecclesiastical and secular, were often not kept as to every crime or sin. And those records that do survive are often fragmentary. More important, the circumstances surrounding the act of infanticide almost dictated a dearth of comprehensive detection and consequent documentation for the following reasons. First, the most common means of infanticide was overlaying (i.e., taking the infant into bed and suffocating it with one's body). Overlaying, of course, could be accidental, but while lack of intent mitigated the degree of penalty, it did not absolve the perpetrator. ${ }^{8}$ Death by overlaying become the concern of the church, exclusively. And the large number of references to it in penitentials and other church documents underlines the fact that it must have been a persistent and quite common problem. Second, it was a secret crime. The evidence (the infant's corpse) could easily be destroyed in the rural environment. Thus, it may be surmised that the church was not cognizant of the majority of infanticides that took place.

Barbara Kellum reports that Columban, in $c .600$, had set penance for overlaying at one year on bread and water and two additional years without flesh or wine. ${ }^{\circ}$ The penance could be reduced if the sinner was a serf or very poor. ${ }^{10}$ This penance became fairly standard, and Kellum points out that it was relatively light "when one considers that the punishment for even accidental killing of an adult was five years, three of these on bread and water". ${ }^{11}$

Bartholomew of Exeter also referred to overlaying in the twelfth century and decreed the standard penance. He also included a new method of commission, that of scalding. ${ }^{12}$ Evidently, such accidents, which occurred while the child was on the hearth, were prevalent enough for inclusion in the penitentials. The thirteenth-century penitential of Thomas of Chobham brought yet other methods of infanticide into official purview, such as refusal to nurse and death by the mother's own hand. ${ }^{18}$ These acts were technically termed homicide, but priests were granted wide discretion (despite the standard three-year penance) in establishing the appropriate punishments.

In addition to penitentials, church legislation of the middle 1200 s repeatedly spoke of the dangers of overlaying, a further testament to its prevalence. As set forth in the Statutes of Winchester I in 1224:

[65] Sub interminatione anathematis sepius in ecclesiis inhibeatur ne mulieres infantulos suos in lectis suis iuxta se collocent ne cos opprimant dormiendo.

Under threat of excommunication from the church, women should be restrained from keeping their children close by in bed lest they smother them while in sleep. ${ }^{14}$

And again in the Constitutiones Cuiusdam Episcopi of $1225 \times 1230$ :

Ibid., pp. 381-382.

- John R. McNeil, and Helena M. Gamer (trans.), Medieval handbooks of penance, New York, Columbia University Press, 1938, p. 254.

${ }^{10}$ Kellum, op. cit., note 4 above, p. 369.

11 Ibid., p. 369.

12 Ibid., p. 370.

12 Ibid., p. 370.

14 F. M. Powiche, Councils and symods with other documents relating to the English Church, II., 1205-1265, Oxford, Clarendon Press, 1964, p. 136 (trans. : Damme). 


\section{Catherine Damme}

[5] Femina etiam moneantur ut pueros suos caute alant, et iuxta se de nocte non collocent teneros ne opprimantur.

Woman again are to be admonished to take care that they do not hold their children close by in the night lest they be smothered. 16

Once more in the Statutes of Conventry issued between 1224 x 1237:

Item, districte precipiatur ut mulla mulier ponat puerum suum in lecto secum, nisi sit ad minus trium annorum vel circiter.

Likewise, it is to be known that no woman lay down her child in bed with her unless it is or is about three years of age. ${ }^{10}$

At least fifteen other references are made in ecclesiastical statutes in the councils of the era to the dangers of taking a child into bed. ${ }^{17}$ While the penance might appear to be shockingly light by modern penal standards, in fact, it was merely a recognition by the church of a method of population control by the poor that may have been necessary, in many cases, for survival.

Another factor discernible among these ecclesiastical statutes is that all admonitions are addressed to females (mulier or femina), never to a male or even parens. Indeed, most prosecutions, both secular and ecclesiastical, were of women; ${ }^{18}$ moreover, from the use of the possessive (suum) with puerum, it is clear that the church was concerned with the classic form of infanticide, i.e., a mother, not an unrelated woman, smothering her infant.

Overlaying, while a sin, was considered a venial one by many penitentials. Evidence of its importance can be found in the following excerpt from Instructions for parish priests in 1359-68:

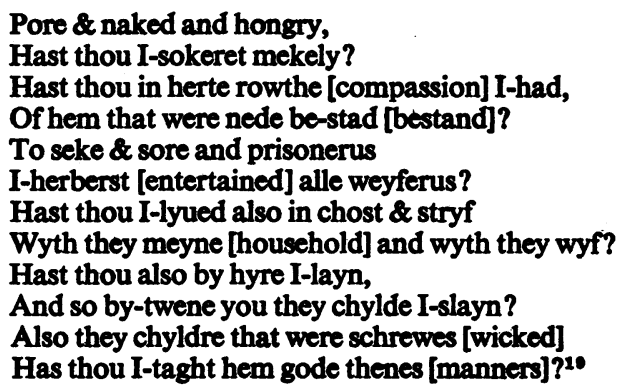

Here the sin of overlaying an infant is juxtaposed with not being a good samaritan and not teaching shrewish children good manners. What might the parish priest have considered appropriate punishment for such minor sins, which here included the taking of a human life?

The penance for overlaying, however, was not always the three-year abstinence discussed earlier, for in the later Middle Ages the penalties were not only more severe,

${ }^{16}$ Ibid., p. 183 (trans.: Damme)

16 Ibid., p. 214 (trans. : Damme)

${ }^{17}$ Ibid., pp. 2, 32, 70, 140-141, 204-205, 214, 234-235, 274, 352, 410, 453, 457, 520, 589-590, 634-635.

18 Helmholz, op. cit., note 7 above, p. 385.

10 Kellum, op. cit., note 4 above, p. 367. 


\section{Infanticide: the worth of an infant under law}

but more publicly stigmatizing. From his review of Coventry church records, Helmholz reports the following:

Joan Rose was convicted at Canterbury in 1470 of killing her son. The judge ordered that Joan should dress in penitential garb and "go before the procession in the parish church of Hythe on three Sundays with a wax candle of half a pound in her right hand and the knife with which she killed the boy, or a similar knife, in her left." She was also ordered to go twice around the markets of Canterbury, Faversham, and Ashford in a similar fashion. This was obviously meant as a humiliating public admission of guilt, and as a warning to others against the crime of infanticide. 20

Helmholz continues that six public whippings were meted out for child suffocation coupled with fornication, and contrasts this to the identical penalty for a man who confessed to fathering a bastard. ${ }^{21}$ A conclusion might be drawn that such a harsh penance for child suffocation as compared to the three-year penance discussed above, may have been a result of the sexual misconduct (fornication) rather than the taking of the infant's life. However, overlaying was elevated in ecclesiastical statutes of Exeter II in 1237 from a venial to a major sin. 22

The variation in penance for overlaying and suffocation points up a characteristic of ecclesiastical justice, that of the wide discretion afforded the parish in setting the penance. Within a parish, bishops, archdeacons, rural deans, capitular bodies, and others all had various degrees of jurisdiction over public sins. ${ }^{23}$ Within this jurisdictional morass, the parish priest, or whichever church official was dealing with the infanticide, was granted a great deal of latitude in fixing penalty. Notwithstanding the precise punishments reviewed herein, there was no "mandatory sentencing," but rather, the officiating body could always look at any mitigating circumstances that might have prompted an act of infanticide.

The most persuasive point for mitigation was, aptly, poverty. Indeed, some penitentials such as that of Columban, institutionalized this. ${ }^{24}$ Another factor the church would take notice of was intent; this was potentially crucial when one considers that the method frequently employed was overlaying.

Discretion was commonly exercised in the burden of proof required in a medieval church court. Upon entering a plea of not guilty, the accused would be required by the judge to bring forward persons (called compurgators) to swear an oath that they believed her (or, occasionally, his) plea. When compurgators were found, came forth and swore, the charge was dismissed. The number of compurgators necessary was established by the court which, in assessing the number, took into consideration the type of crime and the persons and circumstances involved. ${ }^{25}$

Thus, even though medieval society termed an infanticide a homicide, it also realistically looked on it as a phenomenon that took place frequently, within the family, and may have been dictated by pressures of survival. For the poor were, in Mary McLaughlin's words, "at the mercy of the chronic cycles of famine, malnutrition,

\$ Helmholz, op.cit., note 7 above, p. 383.

21 Ibid., p. 384.

22 Mclaughlin, op. cit., note 6 above, p. 157 (note 105).

23 Helmholz, op. cit., note 7 above, p. 385.

${ }^{25}$ Kellum, op. cit., note 4 above, p. 368.

${ }^{25}$ Helmholz, op. cit., note 7 above, p. 383. 


\section{Catherine Damme}

disease and death, and their children were by far the most common victims of the parental negligence and despair, of the abandonment, exposure, and even infanticide, which must be counted among major threats to young life ...". ${ }^{26}$ McLaughlin goes on to point out "[i]f all of these practices were related to the pressures, material and psychological, of a society living often at the limits of subsistence, they are related most specifically to the problem of population, or 'family', control in a time when the means of limiting births were totally inadequate, if not, for practical purposes, virtually non-existent". ${ }^{27}$

Other social motives for infanticide are suggested, particularly the prevalence of promiscuity. Bigamy, a consequence of secret marriages, was quite common, ${ }^{28}$ and controversies over inheritances were legion. ${ }^{29}$ The vulnerability of illegitimate children to infanticide was thus extreme. Another potential victim was the unbaptized child who was thought to be in the power of Satan ${ }^{30}$ Superstitions as to changeling children (i.e., those who cried) who would disappear if placed near the fire on the hearth added to a newborn's peril. ${ }^{81}$ Kellum points out that priests often instructed midwives to perform a "quasi-baptismal" ceremony at the moment of birth for the protection of the neonate. 32

That the church alone took jurisdiction in these matters is in itself of great significance when punishments for infanticide are analysed. For even though the church looked upon infanticide as the taking of another's life, intentionally or negligently, it was estopped by the crown from rendering a judgment that would shed blood (i.e., the death penalty). ${ }^{33}$ Evidently, the taking of an infant's life, while certainly not condoned, was understood. Moreover, a temporary, sometimes a public and humiliating, penance was deemed appropriate and sufficient punishment for this sin.

Although the crown did not normally take jurisdiction over infanticides, some, but very few, references to child-killing in various coroners' rolls can be found. This lack of jurisdiction is understandable in light of ecclesiastical power in the sphere of public sin. However, statutorily at least, in the early twelfth century under the laws of Henry I, the royal courts did take cognizance of the crime if the perpetrator was a person other than the parents. ${ }^{34}$ This was merely the beginning, for as the medieval age drew to a close, royal courts steadily encroached upon ecclesiastical control over this, and indeed most forms, of antisocial (criminal) behaviour.

What did constitute homicide in the King's courts? Fleta defined this crime in the following:

Homicide is the slaying of man by man with evil intent, and there may be bodily slaying either by deed or by word: by deed, as in justice, by necessity, by chance or willfully: by word, as by precept, by counsel or by forbidding. ${ }^{\text {s }}$

${ }^{26}$ McLaughlin, op. cit., note 6 above, p. 119.

27 Ibid., p. 120.

28 Kellum, op. cit., note 4 above, p. 377.

2 Ibid., p. 377.

20 Ibid., p. 377.

${ }^{21}$ Ibid., p. 377.

as Ibid., p. 377.

23 Helmholz, op. cit., note 7 above, p. 384.

"4 McLaughlin, op. cit., note 6 above, p. 157 (note 105).

${ }^{25}$ Richardson and Sayles, op. cit., note 3 above, p. 60. 


\section{Infanticide: the worth of an infant under law}

But he, and his teacher Bracton, expressed strong feelings toward the life of the infant in the form of the viable (quickened) foetus:

He, too, in strictness is a homicide who has pressed upon a pregnant woman or has given her poison or has struck her in order to procure an abortion or to prevent conception, if the foetus was already formed and quickened, and similarly he who has given or accepted poison with the intention of preventing procreation or conception. A woman also commits homicide if; by a potion or the like, she destroys a quickened child in her womb.a"

Fleta also may have given a clue to the prevalence of infanticides of illegitimate infants or grossly deformed neonates, for he defined a freeman as the following:

Among freemen there may not be reckoned those who are born of unlawful intercourse, such as adultery and the like (by-blow, spurious, bastard) and others begotton of unlawful intercourse, nor those who are procreated pervertedly, against the way of human kind, as for example, if a woman bring forth a monster or a prodigy. Nevertheless, the offspring in whom nature has in some small measure, though not extravagantly, added members or diminished them-as if he should have six fingers or only four-he should certainly be included among freemen. Men may also be classified according to whether they are male or female or hermaphrodite. An hermaphrodite, to be sure, is classed with male or female, according to the predominance of the sexual organs. ${ }^{.7}$

Clearly, these pitiful "non-persons" were vulnerable to the murderous attacks of their progenitors.

The child-killing cases that do survive in secular court records are woefully inadequate for analysis. In fact, because the age is almost never recorded, these reports are probably cases of an older child who merits the adult protections of the crown and whose death by suspicious means merits the king's cognizance and justice.

For example, in the Pleas of the Crown at York between 1218 and 1219, the following is recorded:

William son of Lecia was found drowned and Lecia his mother first found him. She has not come, but it is said that she is dead, and the jurors say that she has gone into the land of Jerusalem; and the village of Walton, (near Wakefield) has acknowledged this. Because no one who has been attached can go out of the land before the coming of the Justices, it is adjudged that Lecia's surities are in mercy, namely William the reeve of Walton and Gilbert of Walton. No one is suspected. Judgment, Misadventure."30

The fact that William's death was by drowning, a fairly common form of infanticide according to Kellum, ${ }^{39}$ and the fact that his mother found him, might lead to speculation that William was a victim of infanticide. But, as the cases here are quoted in their entirety, such spare accounts discourage such speculation.

The case of Maleta is also pitiful in its cryptic detail:

Maleta daughter of Walter of Methley was drowned in a ditch. Walter her father found her. No one is suspected. Judgement, Misadventure. ${ }^{40}$

26 Ibid., p. 60.

27 Ibid., pp. 14-15.

28 D. M. Stenton (ed.), Rolls of the Justices in Eyre, Yorkshire, 3 Henry III (1218-1219), London, Bernard Quaritch, Selden Society, 1937, p. 183.

20 Kellum, op. cit., note 4 above, p. 372.

4 Stenton, op. cit., note 38 above, p. 185. 


\section{Catherine Damme}

And again, other drownings are recorded:

Adam of Marr was found drowned. Emma his mother found him. No one is suspected. Judgment, Misadventure."1

Hugh son of Norman in the same way was found drowned. No one is suspected. Judgment, Misadventure."s

A number of cases of this type appear in the Placita Corone, but again, it is doubtful that these are records of infant drownings. In fact, the Latin transcriptions of these cases use the words filius or filia, which convey no age in particular, but suggest something older than infantus.

So while it might be prudent to disregard the majority of drownings, the following case merits more notice:

A two-year-old girl was found drowned in the East ditch (of York). Maud, the nurse found her and has come. No one is suspected. Judgement, Misadventure."s

While this case could not strictly be termed infanticide (the killing of an infant one year or less of age), it is noteworthy for two reasons. First, in light of Henry I's statute then in force (making infanticide committed by someone other than a parent a crime of homicide on par with that of an adult homicide), it is logical that the nurse's discovery of the little girl's death was automatically suspect and warranted a coroner's verdict. Second, the coroner here used puella, rather than filia or femina, to describe the girl. The use of this word coupled with her tender age may strengthen the disregard of the majority of the drownings of various sons and daughters recorded here.

More intriguing are the two other cases in the York rolls that mention pueri, denoting a young male child, although perhaps not an infant:

A boy was found dead shut in a chest in the field of Bilbrough. Serlo of Bilbrough found him and has died. No one is suspected. Judgment, It is not known who he was."

A boy was found dead in an earthen pot in a pit. Amabel found him first, and the jurors say that Hervey Crappes and Agnes his wife are suspected and therefore let them be taken. ${ }^{45}$

The savagery of the above crimes might indicate infanticides carried out in secret upon illegitimate infants. But nothing more is known regarding these deaths. The paucity of information recorded at the medieval inquest is most frustrating. What, for example, was the relationship between Hervey and Agnes Crappes and the dead boy found in the earthen pit, and why did the jurors suspect them? These few cases point out the difficulty of obtaining reliable, factual accounts of secular prosecutions for infanticide.

11 Ibid., p. 203.

12 Ibid., p. 203.

4 Ibid,. p. 288.

4 Ibid., p. 287.

${ }^{e s}$ Ibid., p. 344. 


\section{Infanticide: the worth of an infant under law}

By the late thirteenth century, the Rolls of the Justices of Eyre (rather like circuit courts) were revealing more details of the child murders. A review of two cases, one from 1269 in Bedfordshire, the other from Buckinghamshire in 1363 illustrates the broadened factual base:

It happened in the parish of Ravensden at Sturteslow on Sunday the feast of St. Faith the Virgin about the hour of none [3 p.m. on Sunday, October 6, 1269] in the fifty-third year that John, son of Reginald Reeve of Sturteslow, an infant oneand a half year old, went outside Reginald's door while the latter was at dinner, and fell into a certain ditch and was drowned. Alice, his mother, searched for him, to wit, her infant, and found him drowned. She produced pledges: Arnold Argent and John Yun, both of Ravensden.

Inquest was made before Simon Read, the coroner, by four neighbouring townships, Renhold, Ravensden, Wilden, and Goldington; they say as is aforesaid, and they know nothing else."

It happened at Stone on Wednesday next after the feast of St. Augustine in the thirty-seventh year of King Edward the Third [May 31, 1363] that John Marston found the dead body of a child called Joan, whose death was caused by the boiling water in a brass pot. His pledges are John Moisant and Robert Morti[mer]. The four neighbours are Henry, Robert Fernelourgh junior, William Goodale, and Henry Russ junior; and they are pledges for each other.

Four neighbouring townships, Stone, Stoke-Mandeville, Bishopston, and Dinton, present that on Friday next before Whit Sunday a certain pot full of boiling water stood on the hearth, one of its legs resting on a stone, and it fell from the stone and the boiling water fell upon Joan, Nicholas Ross's daughter, who was a little over half a year old, and thus she came to her death. The pot was worth two shillings. ${ }^{17}$

Here, finally, the ages of the infants are recorded; moreover, the inquest established the accidental circumstances under which death took place. The two methods in evidence here (drowning and scalding) are those which were mentioned frequently in church law on infanticide. Yet, even simple negligence was not alleged. The two cases above also demonstrate the secular parallel to ecclesiastical compurgation, that of producing pledges. These pledges seemed to be a frequent defence employed in secular prosecutions of all types.

Another defence which seems to have been used when secular authorities took jurisdiction over infanticide by a parent was insanity. Barbara Hannawalt, writing on the female felon of the period, points out that the insanity defence was one unique to infanticide:

Cases arising from insanity were among the few in which motivations were fully discussed. Insanity was a fairly uncommon plea in gaol delivery, but of these cases, that of a mother killing her children was the most usual. These unfortunate women all had a history of derangement, or were suicidal, or had been sick with a high fever. Agnes, wife of Roger Moyses, an example of the first type of case, killed her young son, Adam, during one of her frequent bouts of insanity (amentia). Emma, wife of Henry Wolfrom of Cantele, also suffered a period of "demented and vexed" behavior before killing her child. Other women, like Matilda, widow of Mark le Waleys of Buthamwell, tried to commit suicide before returning and murdering the children. Juliana Matta of Killingbury, however, was ill and became crazed from fever. In this state, she drowned her

\footnotetext{
4C Charles Gross (ed.), Select cases from the Coromers' Rolls, A.D. 1265-1413, London, Bernard Quaritch, Selden Society, 1881, p. 13.

17 Ibid., p. 39.
} 


\section{Catherine Damme}

one-year-old son in a well. Sadistic violence might also accompany murders by the insane as it did in the case of Margery, wife of William Calbot, who killed her two-year-old daughter with a knife and forced her four-year-old to sit in the flames of the hearth. The court cases contain insufficient information about the murderesses to label their particular type of mental derangement..8

The insanity defences employed here seem very liberal by the modern standards to be reviewed; however, again most of the victims were over one year of age, and were thus not really subjects of infanticide. This might explain the secular jurisdiction. And Hannawalt goes on to report that "there was only one case of infanticide [the killing of a child under a year old] in 2,933 homicides reported in gaol delivery and coroners' rolls".49

A few other infanticides have been recorded in secular court records, and once again, the insanity plea was readily accepted and the accused acquitted. ${ }^{50}$

Of the secular child-killing cases looked at here, and in nearly all others reported to secular authority that survived, ${ }^{51}$ the courts concluded death resulted from misadventures or accidents. Insanity and pledges were readily accepted by the courts, and no criminal intent was found. Only in the case of Hervey and Agnes Crappes were suspects bound over to receive the king's justice. And, strangely enough, none of the cases involved suffocation by overlaying - the most prevalent method of infanticide. Indeed, most of the cases discussed were probably not those of infanticide, but rather the killing of an older child. Perhaps the crime of infanticide by overlaying and other means, which are so difficult to detect and for which intent is nearly impossible to ascertain, was left to the church.

All the above examples of child-killing repeatedly reinforce the idea that the infant's life was not equal to that of an adult or even a more fully developed child. While ecclesiastical and secular courts called an infant's death homicide, in practice, it was dealt with as something quite less.

\section{EVOLUTION OF INFANTICIDE LAWS IN ENGLAND}

Although the focus of this paper is the attitudes towards infanticide found in medieval England, it is necessary to review how these attitudes, manifested in the legal system, persisted, and can be found in later English statutes. A brief review of these statutes will be useful in tracing the evolution of modern attitudes toward infanticide.

Infanticide continued to occur as England emerged from the Middle Ages and entered the glory of the Elizabethan age. While the church continued to warn its parishioners against this sin, during this time it was being torn asunder by Henry VIII's split from Rome and his founding of the Church of England. The ecclesiastical chaos was continued by his daughter Mary's attempt to reassert the power of the Church of Rome. Finally, the ascension of Elizabeth I to the throne lastingly established the Church of England, independent of the Pope. These upheavals in the church may have

\footnotetext{
48 Barbara Hannawalt, 'The female felon in fourteenth century England', Viator, 1975, 5: 253-268, pp. 260-261.

- Ibid., p. 259.

so Hurnard, op. cit., note 1 above, pp. 161 and 163.

${ }^{51}$ See, e.g., Stenton op. cit., note 38 above, pp. 113 (no. 430), 193 (no. 464), 199 (no. 484), 219 (no 554), 223 (no. 567), 224 (no. 568), 235 (no. 602), 237 (no. 610), 242 (no. 629), 247 (no. 652), 250 (no. 665), 254 (no. 679), 274 (no. 735), 278 (no. 749), 289 (no. 787), 376 (no. 1039).
} 


\section{Infanticide: the worth of an infant under law}

caused secular courts to assert more and more control over public sins such as infanticide. At this time, rapid urbanization was also occurring, and toleration of the secret crime of child destruction became public revulsion at infants' bodies which could no longer be so easily concealed or destroyed in the population-dense cities. At the same time, society was re-examining treatment of children in general; Thomas Phaire's The boke of chyldrun in 1544 introduced more humanitarian methods of child care and paediatrics.

Court records from the Essex Sessions and Assize Records reveal that nearly thirty infanticides in the middle and late sixteenth century were brought to secular authorities, as well as a number of murders of more mature children. ${ }^{52}$ F. G. Emmison reports that "[i]nfanticide was woefully common, and there were probably many other deaths by smothering or bruising which were concealed from the coroner". ${ }^{53}$

Of the thirty infanticides in the Essex rolls, Emmison notes that all but three of the victims were illegitimate. ${ }^{54}$ This is further evidence of the stigmatization that attached to fornication and bastardy resulting from such unions.

A review of some of these infanticides is illuminating:

One spinster, on 21 October 1570 between 12 and 1 a.m. at the house of William Fytche gentleman, her master, at Little Canfield (Hall), gave birth to a dead infant in the backhouse and threw it into his horse pond; no verdict given.

In the house of John Perrye yeoman, her master, at Stanford-le-Hope, [a woman] secretly gave birth at night, after which she cut the baby's throat and threw him into a nearby stream, weighted with stones; guilty.

A baby was born in Cludens Close in Copt Hall Park, Epping, and thrown into the "mud or slud" of the ditch; not guilty, but John Stile did it. [John Stile is the John Doe, or Unknown of the era.]

A servant of Richard Harte of St. Mary's, Maldon, yeoman, bore a daughter without a midwife's aid and put her naked into a chest in the bedroom. Next day she took the infant, then dead, and by the advice of her master, the putative father, buried it in a heap of horse dung in the garden; "not in prison" [refers, presumably to the mother].

An infant, born "without the help of any woman", was strangled.

A widow strangled her newly-born infant; another widow was present and abetted her. The mother was hanged, and the abettor acquitted.

A woman buried her offispring close to the house of William Grey gentleman at Danbury.

A servant of Humphrey Mopted of Frinton yeoman secretly delivered herself and then "defaced" the baby among her pigs; in the jurors' view it was born dead through her negligence in not seeking a midwife's help.ss

The methods used in the above examples are now familiar-asphyxiation by smothering or suffocating, drownings, strangulations and even more gruesome means such

s2 F. G. Emmison, Elizabethan life: disorder (From Essex Sessions and Assize Records), Chelmsford, Essex County Council, 1970, pp. 155-156.

ss Ibid., p. 156.

st Ibid., p. 157.

os Ibid., p. 157. 


\section{Catherine Damme}

as cutting the throat or striking the head on the bedpost. ${ }^{56}$

It was the frequent killings of illegitimate infants that led to new legislation under the Stuart kings. In 1623, an "Act to prevent the destroying and murdering of bastard children" was passed by parliament which stated:

Whereas many lewd Women that have been delivered of Bastard Children, to avoyd their shame and to escape punishment, doe secretlie bury, or conceale the Death of their Children, and after if the child be found dead she said Women doe alleadge that the said Children were borne dead; whereas it falleth out sometymes (although hardlie it is to be proved) that the said Child or Children were murthered by the said Women their lewd Mothers, or by their assent or procurement; For the preventing therefore of this great Mischiefe, be it enacted by the Authoritie of this present Parliament, That if any Woman after one Moneth next ensuing the ends of this Session of Parliament, be delivered of any issue of the Body, Male or Female, which being borne alive, should by the Lawes of this Realm be a bastard, and that she endeavour privatlie either by drowning or secrett burying thereof, or any other way, either by herselfe or the procuring of others, soe to conceale the Death thereof, as that it may not come to light, whether it be borne alive or not, but be concealed, in every such Case the Mother soe offending shall suffer Death as in the Case of Murther except such Mother can make proffe by one Witnesse at the least, that the Child (whose Death was by her soe intended to be concealed) was borne dead.57

In passing this act, parliament was taking cognizance of the great peril to the lives of illegitimate children to which the mores of society had subjected them, and was equating their deaths with murder of an adult. The law also reversed the common law presumption of dead birth. Before passage of the act, in a court proceeding for alleged infanticide, the prosecution had to rebut the presumption that the infant was stillborn (and therefore no crime had been committed). Under the 1623 statute, the accused in such a proceeding would have to rebut the presumption that the child was born alive (i.e., the law presumed a live birth, and thus presumed a crime had been committed because the infant was found dead).

\section{The Old Bailey Sessions Papers (1688) give an example of how this act worked:}

Sinah Jones of the Parish of St. Mary Woolnoth, was Indicted for Murdering her Bastard Male Child, on the eighteenth December last, being Saturday night, by stopping its Breath with a Cloath put in its Mouth; she being a Servant in the House of Mr. Cousins. The Evidence against her was plain, the Nurse, the Chairwoman, the Midwife, the Master and his Servant, all deposing that she, denying the key, they broke open her Trunk, where they all saw the Child Dead wrapped up in a Cloath, with a Rag in the Mouth of it, as big as a Handkerchief, and that the Child being something Warm, they tried all they could to recover Life in it, but to no purpose. The Prisoner said little for herself, but that she knewnothing of the Cloath in the Mouth of the Child, and that she had not her Senses, and was Light-headed. Then the Statute was read to her, wherein, if the Child be found Dead and Concealed, though it were so Born, the Person Concealing it, shall suffer Death as in case of Murder, except she can prove by one Witness at least that the Child so Concealed was born Dead. Upon full evidence, she was brought in guilty of Murder. ${ }^{\text {s8 }}$

Sinah received the death sentence. But what of the prosecution for infanticide when the child was born in wedlock?

se Ibid., p. 157.

21 Jac. I., c27 in D. Seaborne Davies, 'Child killing in English law', Modern Law Rev., 1937, 1: 203-217, p. 213.

s8 J. W. Jeudwine, Observations on English criminal law and Procedure, London, P. S. King, 1968, pp. 126-127. 


\section{Infanticide: the worth of an infant under law}

In the year 1668 at Aylesbury a married woman of good reputation being delivered of a child and not having slept many nights fell into a temporary phrenzy, and kild her infant in the absence of any company; but company coming in, she told them, that she had killed her infant, and there it lay; she was brought to gaol presently, and after some sleep she recovered her understanding, but marvelled how or why she came thither; she was indicted for murder, and upon her trial the whole matter appearing it was left to the jury with this direction, that if it did appear that she had any use of reason when she did it, they were to find her guilty; but if they found her under a phrenzy, tho by reason of her late delivery and want of sleep, they should acquit her; that had there been any occasion to move her to this fact, as to hid her shame, which is ordinarily the case of such as are delivered of bastard children and destroy them; or if there had been jealousy in her husband, that the child had been none of his, or if she hid the infant, or denied the fact, these had been evidences, that the phrenzy was counterfeit; but none of these appearing, and the honesty and virtuous deportment of the woman in her health being known to the jury, and many circumstance of insanity appearing, the jury found her not guilty to the satisfaction of all that heard it. ${ }^{.0}$

Here, society's stigmatization provided a motive to a servant-girl mother to kill her bastard child, but a mother "of good reputation" who killed her legitimate infant appeared to have no motive and consequently must be insane (and could be acquitted). Thus, the insanity plea of a respectable matron of Aylesbury was readily accepted while that of poor Sinah Jones was summarily rejected.

J. W. Jeudwine, commenting on these cases and others, states that "[w]hat probably saved [these women]-in the cases in which they were saved-was the increasing reluctance of juries to convict for murder in such cases [;] [t]hey would grasp at any suggestion that the baby had been stillborn, or had died in the course of birth, or had been accidentally killed". 00

The requirement under the 1623 Act that the accused prove the baby was stillborn was an emormous burden of proof to sustain, and it is not surprising that the statute was repealed in 1803 and replaced by Lord Ellenborough's Act which reinstated the common law presumption of dead (still)birth. That act also provided that women indicted for such offences would be treated under the laws and rules of evidence governing murder indictments except that if the accused were acquitted of murder, the jury could find an alternative verdict of two years' imprisonment if the illegitimate infant's death had been concealed. ${ }^{61}$ Additionally, the 1803 act also made the administration of substances to bring on a miscarriage an offence. ${ }^{\circ 2}$

The law was extended in 1828 to cover mothers of all infants, whether illegitimate or not. ${ }^{03}$ The main thrust of the statute was against concealment; moreover, the act provided that "it shall not be necessary to prove whether the child died before, at, or after birth"."4

There was great reluctance, however, on the part of juries to consider infanticide/ concealments as murders. The last execution for infanticide was in 1849. The verdict was delivered on one Rebecca Smith who, the evidence showed, deliberately poisoned her infant and had probably disposed of other children similarly. ${ }^{65}$ Even though the

so Ibid., p. 127.

0 Ibid., p. 127.

"2 Davies, op.cit., note 57 above, p. 215.

"2 Ibid., p. 215; Jeudwine, op. cit., note 58 above, p. 127.

-2 Davies, op. cit., note 57 above, p. 215.

" Ibid., p. 215.

es Jeudwine, op. cit., note 58 above, p. 128. 


\section{Catherine Damme}

jury found Smith guilty, it disliked the legal connotation of murder and recommended mercy. For the law required that the indictment be brought for murder, not a lesser offence. This dilemma (the inability to indict on a lesser charge) brought about a change in the law in 1861 (The Offenses Against the Person Act, 1861, s.60) to make concealment of a birth a separate substantive crime which applied to any person, not just the mother. ${ }^{86}$

The reluctance, even refusal, of the Crown to seek the death penalty for infanticide was institutionalized when, in 1864, it became the practice of the prosecutor (the Home Office) "to advise the commutation of the death penalty when a woman was convicted of murdering her own child while it was under or not much over the age of twelve months"..67

A great part of this sentiment toward leniency to the mother was based on the almost visceral "feeling" that such a crime simply could not be a rational act, although this feeling was not often articulated. But one commentator before the Capital Punishment Commission did state:

... women in that condition do get the strongest symptoms of what amounts almost to temporary madness, and ... often hardly know what they are about, and will do things which they have no settled or deliberate intention whatever of doing .... . [Y] ou cannot estimate the loss to the child itself, you know nothing about it at all. With regard to the public it causes no alarm, because it is a crime which can be committed only by mothers upon their newly born children."

Jeudwine also recounts the feeling of Justice Bramwell who tried a woman for infanticide:

Another case which I remember was one of the most painful cases that I ever tried. A young women had an illegitimate child a year old: she was very fond of it and behaved well to it. What particular thing so disturbed her I do not know, but I have some reason to suppose that she was about to be married and that a person had threatened to inform her intended husband that his brother was the father of the child. ... On a Sunday morning the child's clothes were hanging before the fire to dry and she was evidently intending to dress it and take it out and use it well, as she had always done. She cut its throat, and she rushed out into the street and said that she had done so. . . . I cannot in my own mind believe that that woman was as mad as the law would require her to be ... but it was an act of such a character that the only address to the jury was "This woman may have had a sudden condition of mind come upon her, in which she really did not know what she was doing." She was a very decent looking young woman; everybody in the court wept, the counsel on both sides and the jury and everybody; and the result was that she was acquitted."

It seems, from the case above, the normal rules of evidence and other legal niceties were cast away during an infanticide trial. Emotional reaction, not the rule of law, was paramount, and the minds of jury and jurist could not accept that such a heinous act could be committed by a rational person - the accused's mind had to be deranged, if only temporarily.

What is unique in the insanity defence for infanticide is its radical departure from

"O Davies, op. cit., note 57 above, p. 216.

27 Jeudwine, op. cit., note 58 above, p. 128.

os Ibid., p. 128.

os Ibid., pp. 128-129. 


\section{Infanticide: the worth of an infant under law}

the normal criminal insanity defence-the McNaughten Rules of $1843 .{ }^{70}$ To plead insanity under the McNaughten rules, the following questions had to be posed: (1) Did the accused know the nature and quality of his act? If not, insanity is a defence. (2) If the accused did know the nature and quality of his act, did he know that it was morally and/or legally wrong? If not, insanity is a defence. ${ }^{71}$

The McNaughten rules applied throughout England and in nearly one-third of United States' jurisdictions. ${ }^{72}$ But McNaughten makes an insanity defence very difficult to prove. Indeed, the standards set by the McNaughten case could not have been met by any of the women acquitted of child-killing because of temporary insanity. Yet these legally untenable insanity pleas were accepted, even solicited, in the case of infanticide by juries and courts and thus stand as a further proof of the special status afforded one accused of infanticide.

English infanticide laws were subjected to many parliamentary attempts at reform in 1872,1874 and 1880 . These attempts may have been a consequence of the deep-seated ambivalence toward the crime: (A) It was homicide under the law, but no jury would convict under those laws and (B) if it was a lesser crime than homicide, no one wanted to admit it, much less write this view into law. The jurists and Members of Parliament found refuge in pinning guilt on the woman's psyche and endocrine system at postpartum; temporary insanity was a convenient loophole. Thus, one finds proposed statutes referencing women as "deprived of their ordinary powers of self-control" (1872), ${ }^{73}$ or "deprived of the power of self-control by any disease or state of mind or body produced by bearing the child whose death is caused." (1874). ${ }^{74}$

The objective of these attempted statutory revisions was to restore to the judge the discretion of reducing the charge from murder to manslaughter and to open the way to an insanity defence.

Finally, in 1922, an Infanticide Bill was passed which allowed a jury to deliver a verdict of murder or manslaughter, without direction from the judge. A judge was permitted to sentence the convicted manslaughterer to anything from life imprisonment to a fine or conditional discharge. ${ }^{75}$ As to laying the groundwork for an insanity plea, the wording was thus:

Where a woman unlawfully by any direct means intentionally causes the death of her newly born child, but at the time ... had not fully recovered from the effect of giving birth to such child, and by reason thereof the balance of her mind was disturbed ...."

Jeudwine puts this legislatively-borne defence into perspective:

he [the drafter of the Bill] felt the need to draft the clause in such a way that it would be selfjustifying -in other words, that the reason for according special treatment to this class of homicide would be evident. Hence his reference to the mother's state of mind. 77

10 Glanville Williams, Criminal Law, 2nd ed., London, Stevens, 1961, ch. 10.

11 Ibid., p. 442.

72 For the most recent insanity rules in U.S. jurisdictions, see U.S. v. Brawner, 471 F. $2 d 969$

(D.C. Cir. 1972).

is Jeudwine, op. cit., note 58 above, p. 129.

"Ibid., p. 129.

76 Ibid., p. 131.

"Ibid. p. 131., " Ibid., p. 131. 


\section{Catherine Damme}

And, having to prove that the balance of the accused's mind was disturbed was a much less onerous burden of proof to sustain than trying to show that she had been "deprived of her ordinary self-control" (the 1872 revision) or did not know the nature and quality of her act (the McNaughten Defence).

The last problem of the Infanticide Act was the ambiguity as to how old a "newly born" child was. When, in 1927, a woman was tried and convicted for murder rather than infanticide because the victim was thirty-five days old and not "newly born", parliament realized clarification was imperative. ${ }^{78}$ This quantitative defect was corrected in the Infanticide Act of 1938 by inclusion of all infants under twelve months of age as subjects of infanticide. ${ }^{79}$

Although prison sentences were mandated by the modern infanticide laws, the following table shows a shift from impositions of penal time to probation (often with psychiatric treatment or commitment to a psychiatric institution).

\section{TABLB $1\left({ }^{(0)}\right)$}

Women Found Guilty of Infanticide in Great Britain And How Courts Dealt With Them

\begin{tabular}{rrrrrc}
\hline Years & $\begin{array}{c}\text { Recognisances } \\
\text { or discharge }\end{array}$ & Probation & Imprisonment & Othera & $\begin{array}{c}\text { Total } \\
(=100 \%)\end{array}$ \\
\hline $1923-27$ & $42.4 \%$ & $5.1 \%$ & $49.1 \%$ & $3.4 \%$ & 59 \\
$1928-32$ & $34.4 \%$ & $18.1 \%$ & $42.6 \%$ & $4.9 \%$ & 61 \\
$1933-38$ & $44.0 \%$ & $22.7 \%$ & $33.3 \%$ & Nil & 66 \\
$1939-45$ & No statistics published & & & \\
$1946-50$ & $24.4 \%$ & $49.0 \%$ & $22.3 \%$ & $4.3 \%$ & 139 \\
$1951-55$ & $15.0 \%$ & $55.0 \%$ & $16.2 \%$ & $13.8 \%$ & 80 \\
$1956-60$ & $9.5 \%$ & $76.2 \%$ & $3.2 \%$ & $11.1 \%$ & 88 \\
$1961-65$ & $5.0 \%$ & $68.1 \%$ & $1.3 \% \mathrm{~d}$ & $25.0 \%$ & 72 \\
\hline
\end{tabular}

a Most of these cases were no doubt committed to institutions for mental defectives or more recently to mental hospital. In 1964 and 1965 the published statistics made it clear that all women not dealt with by discharge, probation, or imprisonment were dealt with by hospital orders.

b In 1923 one of these women was sentenced to 4 years penal servitude another 3 years penal servitude.

c One of these women was sent to a borstal.

d She was sent to prison for 6 months or less.

The table shows an incredible abandonment of prison sentences as a deterrent to or punishment for the taking of a human life. Parallels to medieval penalties (or lack thereof) for infanticide become quite clear and illustrate society's consistent treatment of the infant's life as less than that of an adult under law.

\footnotetext{
78 The woman was immediately reprieved, ibid., p. 132.

20 Ibid., p. 132.

so Ibid., p. 133.
} 


\section{Infanticide: the worth of an infant under law}

\section{THE INFANT'S LIFE IN AMERICAN LAW}

Law in the United States does not exhibit the same preoccupation with infanticide as does English law; in fact, no distinction between homicide and infanticide is made in America. The basic reason for this difference in emphasis lies in the cultural and historical roots of the U.S. legal system.

As a colony of England, the United States was administered under English statutory and common law. After independence, the states adopted the English common law which existed before independence and which then assured continuity of precedent in judicial procedures. The United States had no medieval experience to draw upon other than that of England. Moreover, the colonies that united to form a nation did not have an established church with jurisdiction over public sin. At the time the English jurists were carving out a distinction for infanticide in law (1803), America had just begun developing its own legal system within the traditions of its inherited common law.

It is easier to ascertain English attitudes toward infanticide because nearly all statutes are national in scope-i.e., they pertain to the whole of the United Kingdom. Thus, all the provincial governments have one uniform homicide law and one body of law relating to the infant.

However, the United States adopted a federalist system, reserving for the states all those rights and powers not specifically delegated to the federal government in the U.S. Constitution. Each state, then, developed its own body of law (and precedent flowing therefrom) but, of course, within the constricts of the Constitution. Therefore, each state has its own penal code and homicide statutes; there is no national homicide law. America's legal history of infanticide has thus been truncated by its colonial status and fragmented by its federal system. No laws proscribing infanticide exist, no legislative battles as to its status have ever been waged in the U.S. Congress as they were in the British Parliament, and the crime is wholly under the aegis of state homicide statutes.

However, some vestiges of the medieval society's lack of regard for the infant's life can be discovered in American law. The state can legitimately protect the health and welfare of infants, and it exercises this power in many ways including determining custody and guardianship of children and prosecuting parents for child abuse. However, my review here will be limited to legal implications of certain activities in which parents (and other persons) have life and death power over infants or potential infants: (1) abortion, (2) proxy consent to medical treatment, and (3) euthanasia of defective newborns.

Under what law or legal theory can the state protect the infant? A well-established duty of the state to its citizens is the protection of their health, safety and welfare. This duty imparts a power (commonly called the "police power") to the state by which it can achieve protection of infants' (and all citizens') lives. The police power to protect is not unbridled; the parameters of it are delineated by statute, by the U.S. Constitution, and by judicial decisions. Nor are the parameters static, but rather are a dynamic process always in flux in response to a society's values.

A crucial constitutional restriction upon the state's power is the body of rights granted to individual citizens and guaranteed within the U.S. Constitution. Thus, an action taken by the state to protect an infant may run counter to an individual's freedoms. Courts must then decide which value should prevail: the state's interest in its citizens 


\section{Catherine Damme}

or the individual's right to be free of state interference or control.

In balancing the individual's claim of unconstitutional restriction of his freedoms against the state's need to protect the public health and safety, the courts have developed a number of criteria to be met in the legitimization of a proposed action or statute. To determine the proper balance of rights versus interests, the courts usually apply a "minimum scrutiny" test for determining the constitutionality of various state actions. In a "minimal scrutiny" test, the court looks at a state statute or action with a strong presumption that it is valid. With this presumption, the court will not disturb state activities unless they blatantly lack a reasonable relationship to a legitimate state interest or unless they are arbitrary, capricious, or overbroad for their purpose.

However, this discussion must centre on the state's interest in the lives of infants both in rerum natura and in utero. Because such interests may collide with certain constitutional rights of parents (privacy rights or freedom to practise religion), a more rigorous judicial test-that of "strict scrutiny,"-must be analysed.

Courts have termed a "strict scrutiny" test one which is applied when fundamental rights protected in the Bill of Rights (such as those of assembly, movement, religion, or privacy in sexual or procreational activities) have been involved or when a suspect classification (race, alienage, ethnicity) has resulted. ${ }^{81}$ The strict scrutiny test (also called the "compelling state interest" test) differs from that of minimal scrutiny in that the state action challenged must not merely be rationally related to the accomplishment of a legitimate state interest; rather, it must be necessary to the accomplishment of a compelling state interest and must employ the least restrictive means to achieve its end.

There are many cases in which the compelling state interest argument has been pivotal, ${ }^{82}$ but it was not until 1965 that the Supreme Court established the constitutionally protected right of privacy. In Griswold v. Connecticut, ${ }^{83}$ the U.S. Supreme Court struck down a Connecticut statute that prohibited the use of contraceptives, and in doing so prohibited the state from interfering with the privacy surrounding the "intimate relation of husband and wife and their physician's role in one aspect of that relation". ${ }^{84}$ Once the privacy zone around the marital relationship was established, it was expanded in a 1972 case. In Eisenstadt v. Baird, ${ }^{85}$ the high court, applying the equal protection clause of the Fourteenth Amendment, extended Griswold to include the right of single persons to use contraceptives. ${ }^{86}$

${ }^{21}$ See, e.g., Loving v. Virginia, 388 U.S.1. 87 S. Ct. 1817, 18 L. Ed. $2 d 1010$ (1967) "suspect classification" by race; Graham v. Richardson, 403 U.S. 365, 91 S. Ct. 1848, 29 L. Ed. 2d 534 (1971) "suspect classification" of aliens; Hernandez v. Texas, 347 U.S. 475, 745 S. Ct. 667, 68 L. Ed. 866 (1954) "suspect classification" by national origin.

${ }^{82}$ See, e.g., NAACP v. Button, 371 U.S. 415 (1963); Bates v. Little Rock, 361 U.S. 516 (1964); Sherbert v. Verner, 374 U.S. 398 (1963).

8 Griswold v. Connecticut, 381 U.S. 479 (1965).

s4 Ibid., p. 484

${ }^{8 s}$ Eisenstadt v. Baird, 405 U.S. 438 (1972).

se Ibid., p. 453. Justice Brennan said: "If under Griswold the distribution of contraceptives to married persons cannot be prohibited, a ban on distributions to unmarried persons would be equally impermissible ... If the right of privacy means anything, it is the right of the individual, married or single, to be free from unwarranted governmental intrusion into matters so fundamentally affecting a person as the decision whether to bear or beget a child." 


\section{Infanticide: the worth of an infant under law}

Griswold and Eisenstadt laid the legal groundwork for the decision on the personhood of the foetus under law. In 1973, the issue of abortion was confronted by the Supreme Court in Roe v. Wade. ${ }^{87}$ The court ruled that the zone of privacy was found to be "broad enough to encompass a woman's decision whether or not to terminate her pregnancy". ${ }^{88}$ The court thus established the zone of privacy around the woman and her physician. During the first trimester the decision to abort would lie within this zone and could not be disturbed by the state. ${ }^{80}$ But, after the first trimester, "the state ... may if it chooses, regulate the abortion procedure in ways that are reasonably related to maternal health." proscribe, abortion except ... for the preservation of the life or health of the mother." 91

Here is the leading jurisprudential articulation of when the infant in utero reaches that level of maturity which justifies state intervention despite the constitutional rights of the mother. However, even at viability, the mother's life and health are paramount to the state's interest in protection of the life of the viable foetus who is only a potential person.92

Roe did not signal a retreat from state protection of the foetus as a person, but rather, reaffirmed the pre-eminent status of the woman and the lesser (indeed non-) status of the foetus. For before Roe, the status of the foetus as a person under law was not clearly defined in the state statutes proscribing abortion (which were invalidated by $R o e$ ). These statutes, although occasionally purporting to protect the foetus and future infant, in fact protected the mother. The myth of the blameless mother which evolved in medieval England was present in these American state statutes on abortion. For example, under most of the state laws, the woman was considered to be the victim of the abortionist and not the perpetrator of the crime. ${ }^{93}$ Women were seldom prosecuted for seeking and obtaining an illegal abortion. Usually, the pregnant woman was not even thought to be an accomplice, ${ }^{94}$ notwithstanding the fact that she willingly submitted to an abortion.95

The court in Roe brought out the hypocrisy of the appellee's argument that the Texas abortion statute was necessary to protect the person of the foetus:

When Texas argues that a fetus is entitled to Fourteenth Amendment protection as a person, it faces a dilemma.

Neither in Texas nor in any other State are all abortions prohibited. Despite broad proscription, an exception always exists. (Saving the mother's life is a typical exception). But if a fetus is a person who is not to be deprived of life without due process of law, and if the mother's condition is the sole determinant, does not the Texas exception appear to be out of line with the Amendment's command?

${ }^{87}$ Roe v. Wade, 410 U.S. 113 (1973).

ss Ibid., p. 153.

"Ibid., p. 163.

${ }^{\infty}$ Ibid., p. 163.

11 Ibid., pp. 164-165.

02 Ibid., p. 154.

1 C.J.S. Abortion 14 (1936) note 48.

" Ibid., note 49.

95 Ibid., note 50 . A few courts have held that a mother is a participant and legally responsible for her act of submission. On rare occasions she was prosecuted as a principal in the crime, or for selfinduced abortion. In certain states there was statutory punishment for the woman who caused a selfabortion or who submitted her body for one. See, generally, 1 C.J.S. Abortion 14, notes 51, 52,52. 5, 47. 


\section{Catherine Damme}

There are other inconsistencies between Fourteenth Amendment status and the typical abortion statute. It has already been pointed out ... that in Texas a woman is not a principal or an accomplice with respect to an abortion upon her. If a fetus is a person, why is the woman not a principal or accomplice? Further, the penalty for criminal abortion (in Texas and most states) is significantly less than the maximum penalty for murder. . . . If the fetus is a person, may the penalties be different?

Thus, the Court acknowledged that a foetus cannot merit the protection of the state as a person. Such a position echoes the medievalist's view of the infant's lesser status in Roe v. Wade, and the state abortion statutes it struck down.

Yet the interest in life of the infant in rerum natura has been upheld over the rights of the parents in other areas of the law. In medical treatment of minors, the infant can invoke the state's protection against parental wishes which are life-threatening.

Under law, parents have a primary interest in the upbringing of the children. However, the state retains an overriding interest (as parens patriae) in the health, safety and welfare of the child. Ordinarily, medical treatment to an infant is administered only after informed consent has been obtained from the infant's parent or guardian. At common law, minors were considered incapable of giving valid consent..$^{97}$ Recognized exceptions are medical emergencies where treatment must be rendered immediately and statutory provisions which authorize a minor's consent to therapy under certain circumstances, such as venereal disease. ${ }^{98}$ Proxy consent of parents for performance of surgery on a child is not often challenged because the procedure is usually for the child's benefit. ${ }^{90}$

's Roe v. Wade, op. cit., note 87 above, p. 157 , note 54.

"7 See e.g., Bonner v. Moran, 126 F. 2 d 121 (D.C. Cir. 1941); Zaman v. Schultz, 19 Pa. D. \& C. 309 (1932).

os E.g., 35.03, Texas Family Code (1975): Ch. 35; 35.03. Consent to Treatment by Minor: (a) A minor may consent to the furnishing of hospital, medical, surgical, and dental care by a licensed physician or dentist if the minor: (1) is on active duty with the armed services of the United States of America; (2) is 16 years of age or older and resides separate and apart from his parents, managing conservator, or guardian, whether with or without the consent of the parents, managing conservator, or guardian and regardless of the duration of such residence, and is managing his own financial affairs, regardless of the source of the income; (3) consents to the diagnosis and treatment of any infectious, contagious, or communicable disease which is required by law or regulation adopted pursuant to law to be reported by the licensed physician or dentist to a local health officer; (4) is unmarried and pregnant, and consents to hospital, medical, or surgical treatment, other than abortion, related to her pregnancy; (5) is 18 years of age or older and consents to the donation of his blood and the penetration of tissue necessary to accomplish the donation; or (6) consents to examination and treatment for drug addiction, drug dependency, or any other condition directly related to drug use. (b) Consent by a minor to hospital, medical, surgical, or dental treatment under this section is not subject to disaffirmance because of minority. (c) Consent of the parents, managing conservator, or guardian of a minor is not necessary in order to authorize hospital, medical, surgical, or dental care under this section. (d) A licensed physician or dentist may, with or without the consent of a minor who is a patient, advise the parents, managing conservator, or guardian of the minor of the treatment given to or needed by the minor. (e) A physician or dentist licensed to practice medicine or dentistry in this state or a hospital or medical facility shall not be liable for the examination and treatment of minors under this section except for his or its own acts of negligence. (f) A physician, dentist, hospital, or medical facility may rely on the written statement of the minor containing the grounds on which the minor has capacity to consent to his own medical treatment under this section.

"O When such a benefit to the child has been in question, however, physicians have sought guidance from the courts. In 1957, the Massachusetts Superior Court reviewed parental consent to kidney transplant surgery between twin sons aged nineteen, one of whom was suffering from glomerulonephritis. The surgeons petitioned the court to rule on the adequacy of the parents' consent to removal 


\section{Infanticide: the worth of an infant under law}

It is when an infant is in need of some medical procedure and the parents refuse to consent, that the courts are most often called upon to assert the state's interest in the infant's life. Decisions authorizing state intervention are often based on the courts' interpretation of child neglect statutes which results in a finding of neglect or dependency. In addition, courts balance the parents' fundamental freedom of religion and rights of privacy protected by the Constitution against the state's compelling interest in the preservation of the lives of its citizens.

The situation is clearly drawn when the medical treatment is needed immediately and is one which has a high success rate with an accompanying low risk. Such was the case in People ex rel. Wallace v. Labrenz, ${ }^{100}$ wherein an infant suffering from erythroblastosis fetalis was given a blood transfusion under authority of a court-appointed guardian. The parents had refused to consent to a transfusion because such a procedure violated their religious beliefs as Jehovah's Witnesses. The Illinois Supreme Court upheld the constitutionality of the lower court's action, and, citing Prince v. Massachusetts, ${ }^{101}$ stated "neither rights of religion or rights of parenthood are beyond limitation .... The right to practice religion freely does not include liberty to expose the community or the child to communicable disease or the latter to ill health or death. . ." ${ }^{102}$ Nearly all jurisdictions have uniformly held that parents' religious objections to blood transfusions can be overruled by the state when the procedure is necessary to save the life of an infant. ${ }^{103}$

The courts have even ordered such transfusions in the case of an adult with minor children who refused a blood transfusion. ${ }^{104}$ However, where minor children were not involved, some courts have not interfered with an adult's refusal to allow a needed blood transfusion. ${ }^{105}$ Moreover, where the life of the infant is so inextricably intertwined with that of the adult, the court will again order a transfusion to a patient of the Jehovah's Witness faith. In Raleigh Fitkin-Paul Morgan Memorial Hospital, etc.

of a kidney from the healthy twin. Where was the benefit? In finding the parents' consent sufficient, the court looked to psychiatric testimony to find an emotional "benefit" in being a donor as well as an emotional detriment if the transplant were prohibited and the other twin died. In addition to the psychological considerations, the court also based its decision on the ability of the healthy nineteenyear-old to comprehend the nature and risks of the surgery. Two other cases involving fourteen-yearolds were decided on similar grounds. See Masden v. Harrison, no. 68651 Eq., Mass. Sup. Jud. Ct. 12 June, 1957; Husky v. Harrison, no. 68666 Eq., Mass. Sup. Jud. Ct., 30 August, 1957; Foster v. Harrison, no. 68674 Eq., Mass. Sup Jud. Ct., 20 November, 1957; but see, Strunk v. Strunk, 445 S.W.2d 145 (Ky. 1969); In re Guardianship of Pescinski, 226 N.W.2d 180 (Mich. 1975) where the courts deal with the issue of proxy consent to kidney transplant surgery involving incompetent donors.

100 People ex rel. Wallace v. Labrenz, 411 IIl. 618, 104 N. W. 2d 769 (1952), cert. den'd., 344 U.S. 824 (1952).

${ }^{101}$ Prince v. Massachusetts, 321 U.S. 158 (1944); see alse People v. Pierson, 176 N.Y. 201, 68 N.E. 243 (2903).

${ }^{102}$ Prince v. Massachusetts, ibid., p. 166.

102 People ex rel. Wallace v. Labrenz, op. cit., note 100 above; State v. Perricone, 181 A. 2 d 751 (N.J. 1962); Wingard Petition, 7 Pa. D.\&C.2d 522 (Co. Ct. 1956); Morrison v. State, 252 S.W. 2d 97 (Mo. 1952); Hoener v. Bertinato, 171 A. 2d 140 (N.J. Sup. 1961); In re Santos, 227 N.Y.S. 2d 450, app. dissm'd., 232 N.Y.S. $2 d 621$ (1965).

${ }^{104}$ See, e.g., Application of the President and Directors of Georgetown College, 331 F.2d 1000 (D.C.Cir. 1964), re-hearing den'd., 331 F. 2d 1010 (D.C.Cir. 1964), cert. den'd., 377 U.S. 978 (1964).

${ }^{105}$ See e.g., In re Brooks' Estate, 32 Ill.2d 361, 205. N.E.2d 435 (1965); Erickson v. Dilgard, 44 Misc. 2d 27, 252 N.Y.S.2d 705 (1962). 


\section{Catherine Damme}

v. Anderson, ${ }^{106}$ the court ordered a transfusion to a pregnant woman at term by clearly basing its decision on saving the life of an infant (represented by the viable foetus) in which it said the state had a vital interest. Here, the infant's interest in life appears equal if not superior to that of an adult; however, we should note that the court in Raleigh was not faced with a choice between the mother's life and that of her child. Rather, there were strong policy reasons for saving the mother's life against her will.

A much more difficult question is presented when the child's life is in no immediate danger and when the state's intrusion conflicts with the parents' religious beliefs. ${ }^{107}$ These issues are less clear because then courts are asked to rule on procedures which will affect the quality of life and not life itself. But whatever the fact situations, in every case the courts must weigh the rights of the individual to be left alone, to practise his religion, to raise his children, or even to die, against the interests of the state in protecting and preserving the lives of its citizens.

However, legal implications of abortion and parental proxy consent are ancillary to the issue of infanticide in the United States. There is no special law or statute in any state setting forth penalties for killing an infant of less than twelve months. Any such acts are considered under state homicide statutes. It is interesting to note, however, that almost no prosecutions for infanticide exist. Those that have been reported usually involve a person other than the mother. One such case was Morgon v. State, ${ }^{108}$ wherein a newly born illegitimate infant was found dead in a stream. The putative father admitted to being brutal to the mother which caused a miscarriage, and, he alleged, a stillbirth. Of the three physicians who examined the body, two declined an opinion, and the third stated that the infant had been born alive. Additional medical testimony showed that the infant's lungs had air in them. However, the father's conviction of second degree murder was reversed on appeal because, in the opinion of the court, there was not enough evidence that the victim had been born alive to sustain a conviction. And in order to convict of murder, the court said, the infant must have "become a reasonable creature in being." 109

This case points out a reluctance to convict a putative father of infanticide even with fairly strong medical testimony indicating a live birth. Such an outcome is very reminiscent of the English cases reviewed here.

What is even more convincing of the special status granted infanticide in this country is not the few cases that are reported but rather, the dearth, indeed the almost total absence, of such prosecutions at all.

In medieval England, parents often had the power of life and death over their infants. Today, a remnant of such power survives in American decisions regarding treatment of defective newborns. Although it has not been widely discussed in the medical literature, many obstetricians admit to delivering infants so severely deformed that they have not taken measures (often even ordinary measures) to sustain the infant's life, preferring to

\footnotetext{
106 Raleigh Fitkin-Paul Morgan Memorial Hospital etc. v. Anderson, 42 N.J. 421, 201 A.2d 537, (1964), cert. den'd., 377 U.S. 985 (1964).

${ }_{107}$ See, e.g., Muhlenberg Hospital v. Patterson, 320 A.2d 518 (N.J. 1974). In re Sampson, 317 N.Y.S.2d 641 (1970), aff., 323 N.Y.S.2d 853 (1971), aff. per curiam, 328 N.Y.S.2d 687 (1972); In re Green, 292 A. 2d 387 (Pa. 1972), 307 A.2d 279 (Pa. 1973).

${ }^{108}$ Morgon v. State, 256 S.W. 433 (Tenn. 1923).

100 Ibid., p. 434.
} 


\title{
Infanticide: the worth of an infant under law
}

let life expire in the delivery room. As medical technology has advanced, the ability and opportunity to sustain life in such infants has presented serious ethical questions. No legal actions have ever been taken in regard to these delivery room deaths. What is noteworthy is that the life and death decisions are made without benefit of due process of law or even any institutionalized guidelines from a hospital or professional association. Rather, these decisions are made quickly in a delivery room within a short timespan. Society implicitly trusts the physician's judgment as to the prognosis for the infant.

If the physician chooses to place a deformed infant in a special-care or intensivecare nursery, the decision of life or death is shifted from physician (in the emergency context of the delivery room) to the parents. Then the decision becomes whether to withdraw medical treatment and allow a seriously deformed infant to die. One such situation was poignantly described by Dr. Raymond S. Duff and Dr. A. G. M. Campbell at Yale-New Haven Hospital:

\begin{abstract}
[A] child had had chronic pulmonary disease after positive-pressure ventilation with high oxygen concentrations for treatment of severe idiopathic respiratory-distress syndrome. By five months of age, he still required 40 percent oxygen to survive, and even then, he was chronically dyspneic and cyanotic. He also suffered from cor pulmonale, which was difficult to control with digoxin and diuretics. The nurses, parents and physicians considered it cruel to continue and yet difficult to stop. All were attached to this child, whose life they had tried so hard to make worth-while. The family had endured high expenses (the hospital bill exceeding \$15,000), and the strains of the illness were believed to be threatening the marriage bonds and to be causing sibling behavioral disturbances. Oxygen supplementation was stopped, and the child died in about three hours. The family settled down and in 18 months had another baby, who was healthy. ${ }^{110}$
\end{abstract}

The parents, here, chose death for their infant without fear of legal liability. ${ }^{111}$ The propriety of parental proxy consent to death was not questioned. The state has never definitively stepped in to control this decision or uphold the infant's right to life, however deformed or retarded that life may be. Are infants special? Would the state have interfered if the parents had attempted to make such a decision for an adult relative or a more fully matured infant?

The answer can be found in the case of In the matter of Karen Quinlan. ${ }^{112}$ There the plaintiff-parents sought to withdraw Karen (then comatose and in a vegetative state) from life-sustaining medical care. Although such decisions are routinely, yet painfully, made by parents of defective newborns without state interference, for Karen, an adult, the state did intervene to protect her interests in life. Although the Supreme Court of New Jersey ultimately ruled to restore the decision-making power to Karen's parents (in consultation with her physicians), what is important is that the state felt compelled to intervene to protect Karen. Situations similar to Quinlan's arise frequently in the special-care nurseries in paediatric hospitals, yet the state does not assert an interest.

The only conclusion that can be drawn is that the infant does indeed have lesser

${ }^{110}$ Raymond Duff and A. G. M. Campbell, "Moral and ethical dilemmas in the special care nursery", New Engl. J. Med., 1973, 289: 890-894, pp. 891-892. 1974.

111 But see, Marine Medical Center et al. v. Houle, No. 74-145 Civ., Maine Sup. Ct., 14 February,

${ }_{112}$ In re Quinlan, 137 N. J. Super. 227, 348 A. 2d 801 (Ch. Div. 1975), rev'd., 70 N.J.10, 355 A.2d 647 (1976). 


\section{Catherine Damme}

status in law than the adult. Such status does not represent an erosion of ethical or religious values nor is it evidence of a brutal society, but rather demonstrates society's continued ambivalence toward the inherent sanctity of life and realistic judgment on the quality of life.

\section{SUMMARY}

Medieval values and customs relating to the relative worth of the neonate under law have been examined here in some depth. This examination has illustrated the lower status in which the infant was held by society and has shown that this position has been institutionalized in English laws on infanticide which prescribe lesser penalties than those for homicide as well as establish a very liberal insanity defence. The American jurisprudential system has inherited, to a degree, the English attitudes toward the infant as evidenced in state abortion statutes, Roe $v$. Wade, parental proxy-consent to medical treatment, condonation of euthanasia of defective newborns, and the virtual absence of infanticide prosecutions. 